\title{
PENDAMPINGAN PROGRAM PENGENDALIAN INFLASI DAERAH PADA KLASTER CABAI MERAH
}

\author{
Ida Marina*, Sri Ayu Andayani, Dinar, Umar Dani , Kosasih Sumantri \\ Fakultas Pertanian Universitas Majalengka \\ *idamarina@unma.ac.id
}

\begin{abstract}
Inflationary pressure in West Java province in January to March 2021 (quarter 1) was lower than October to December 2020 (quarter IV), the lower inflation rate was caused by limited demand due to the implementation of Restrictions on the activities of the Javanese Community West (PPKM) and controlling the supply of food commodities because the harvest has just begun for several food commodities, including red chili. Red chilies experienced an increase in prices due to the La Nina weather factor so that farmers failed to harvest and limited supplies. In an effort to maintain price affordability and supply availability to mitigate existing risks. Assistance is provided to the red chili cluster in the Mekar Mulya farmer group with the aim of supporting the TPID program with a $4 K$ framework (Price Affordability, Supply Availability, Smooth Distribution, and Effective Communication)

Keywords: Inflation, Red Chili Cluster, Supply Availability
\end{abstract}

\begin{abstract}
Abstrak
Tekanan inflasi di provinsi Jawa Barat pada bulan Januari sampai bulan Maret 2021 (triwulan 1 ) lebih rendah dibandingkan dengan bulan Oktober sampai bulan Desember 2020 (triwukan IV), laju inflasi yang lebih rendah tersebut disebabkan oleh permintaan yang masih terbatas akibat pemberlakuan Pembatasan aktivitas Masyarakat Jawa Barat (PPKM) dan pengandalian pasokan komoditas pangan karena baru dimulainya masa panen pada beberapa komoditas pangan diantaranya cabai merah. Cabai merah mengalami peningkatan harga yang disebabkan faktor cuaca La Nina sehingga petani gagal panen dan terbatasnya pasokan. Dalam upaya menjaga keterjangkauan harga dan ketersediaan pasokan untuk memitigasi resiko yang ada. Pendampingan dilakukan pada Klaster cabai merah di kelompok tani Mekar Mulya dengan tujuan untuk mendukung program TPID dengan kerangka 4K (Keterjangkauan Harga, Ketersediaan Pasokan, Kelancaran Distribusi, dan Komunikasi Efektif)

Kata Kunci : Inflasi, Claster Cabai Merah, Ketersediaan Pasokan
\end{abstract}

\begin{tabular}{l|l|l} 
Submitted: $2021-06-19$ & Revised: 2021-07-13 & Accepted: 2021-07-31
\end{tabular}

\section{Pendahuluan}

Peningkatan permintaan komoditas dan produk berbasis cabai terus mengalami peningkatan secara signifikan dari waktu ke waktu. Peningkatannya terus meningkat sejak tahun 2017 sampai sekarang dan diprediksi akan terus meningkat. Hal ini dapat dipahami bahwa komoditas cabai merah menduduki posisi penting sebagai menu pangan, meskipun penggunaannya dalam jumlah kecil, namun hampir seluruh menu masakan di Indonesia menggunakan cabai merah (Pusdatin,2016).

Permasalahan yang muncul pada komditas cabai merah meliputi interpretasi permintaan dari konsumen kepada produsen serta menginformasikan produk yang diproduksi produsen kepada konsumen melalui penyaluran produk dan jasa-jasa pemasaran serta menyelaraskan proses pemasaran yang diakibatkan oleh adanya dinamika permintaan pasar dan preferensi konsumen (Saptana dan Rahman, 2015).

Selain itu, cabai merah dihadapkan pada faktor cuaca sebagai penyebab gagal panen dan terbatasnya pasokan. Dalam rangka menjaga ketersediaan pasokan dan keterjangkauan harga dilakukan pengendalian pada claster cabai merah untuk memitigasi berbagai risiko yang ada, sebagai salah satu upaya mendukung program Pengendalian Implasi Daerah. seluruh program TPID dijalankan sesuai dengan kerangka strategi 4K, yaitu (1) Menciptakan Keterjangkauan Harga, (2) Menjamin Ketersediaan Pasokan, (3) Memastikan Kelancaran Distribusi, dan (4) Melakukan Komunikasi Efektif untuk menjaga ekspektasi inflasi masyarakat. Dalam pelaksanaannya, sinergitas 
dan kolaborasi antara instansi/lembaga terkait serta akademisi baik di tingkat provinsi maupun tingkat kabupaten/kota di Jawa Barat dalam Tim Pengendalian Inflasi Daerah (TPID) menjadi concern utama dalam melakukan upaya pengendalian inflasi sekaligus dalam rangka mendukung pemulihan ekonomi.

Metode Pengabdian Kepada Masyarakat (PKM) yang dilakukan yaitu dengan cara memberikan pendampingan kepada klaster cabai merah di kelompok tani Mekarmulya. Pendampingan tersebut mengangkat judul "Pendampingan Program Pengendalian Inflasi Daerah Pada Klaster Cabai Merah". Tujuan dari pengabdian kepada masyarakat ini yaitu untuk mendukung program TPID dengan kerangka 4K (Keterjangkauan Harga, Ketersediaan Pasokan, Kelancaran Distribusi, dan Komunikasi Efektif).

\section{Metode}

Kegiatan PKM dilakukan dengan beberapa tahapan kegiatan. Tahap pertama tim PKM Melakukan komunikasi, koordinasi dan kolaborasi, dengan instansi/lembaga terkait serta stakeholder meliputi ; Pemerintah Daerah Kabupaten Majalengka, Dinas Pertanian Kabupaten Majalengka, Departemen Pengembangan UMKM dan Perlindungan Konsumen, Bank Indonesia Cabang Cirebon, Pemerintah Setempat, Asosiasi Pasar Tani (ASPARTAN), Perbankan, Perusahaan Benih, Kelompok Tani dan Pelaku Pasar Digital. Tahapan kedua yaitu pendampingan pada kelompok tani Merkarmulya yang dilakukan secara kolaborasi, antara instansi/lembaga terkait dan stakeholder secara berkelanjutan sesuai dengan kapasitas, fungsi, tugas dan wewenang dari masing-masing pihak. Waktu pelaksanaan pendampingan dilakukan setiap bualan disesuaikan dengan kebutuhan dan kajian serta penerapan informasi teknologi.

\section{Hasil dan Pembahasan}

Pada bulan April 2021, Jawa Barat mengalami inflasi sebesar 0,22\% $(\mathrm{mtm})$ atau sebesar 1,52\% (yoy). Laju inflasi ini lebih tinggi dibanding April 2020 yang tercatat sebesar 0,13\% (mtm) tetapi lebih rendah dibandingkan dengan inflasi tahunan pada April 2020 yang sebesar 3,77\% (yoy) (Bank Indonesia,2021). Berdasarkan kelompok penyumbang inflasi, tekanan inflasi didorong salah satunya oleh Kelompok Makanan. Komoditas Cabai merah termasuk kelompok makanan penyumbang inflasi. Kecamatan Argapura Kabupaten majalengka merupakan salah satu sentra produksi komoditas cabai merah di Jawa Barat dengan wilayah pemasaran Bandung, Jakarta, Cirebon dan sekitarnya. Produksi cabai merah di Argapura diusahakan oleh kelompok tani Mekarmulya pada area lahan 25 ha dengan anggota sebanyak 25 orang.
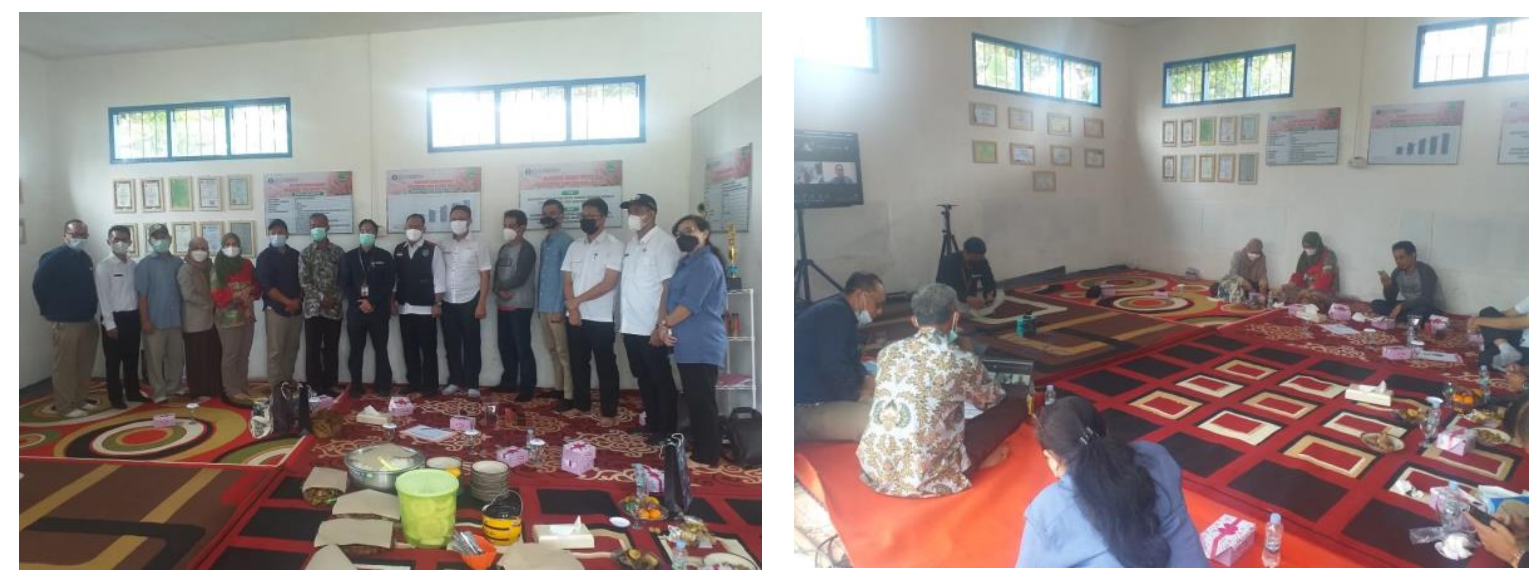

Gambar 1. Kolaboratif Pendampingan Pengendlian Inflasi Daerah Di Kelopok Tani 
Kegiatan pendampingan yang dilakukan Tim PKM berupa pengendalian produksi (peramalan produksi dan permintaan) yang berasal dari hasil penelitian yang telah dilakukan sebelumnya yaitu perencanaan produksi untuk meramalkan (forecasting) permintaan di masa yang akan datang sehingga produsen dapat memperkirakan kapasitas produksi (Marina,2017). Hal ini dapat dijadikan referensi penanaman cabai merah berupa waktu tanam. Bank Indonesia (BI) memberikan pendampingan dan bantuan berupa pompa air dan penampungan, Jalan ke jalur Usahatani, Renovasi sarana Ibadah Sedangkan TPID melakukan pendampingan berupa Keterjangkauan Harga, Ketersediaan Pasokan, Kelancaran Distribusi, dan Komunikasi Efektif dapat dijelaskan pada gambar 2.

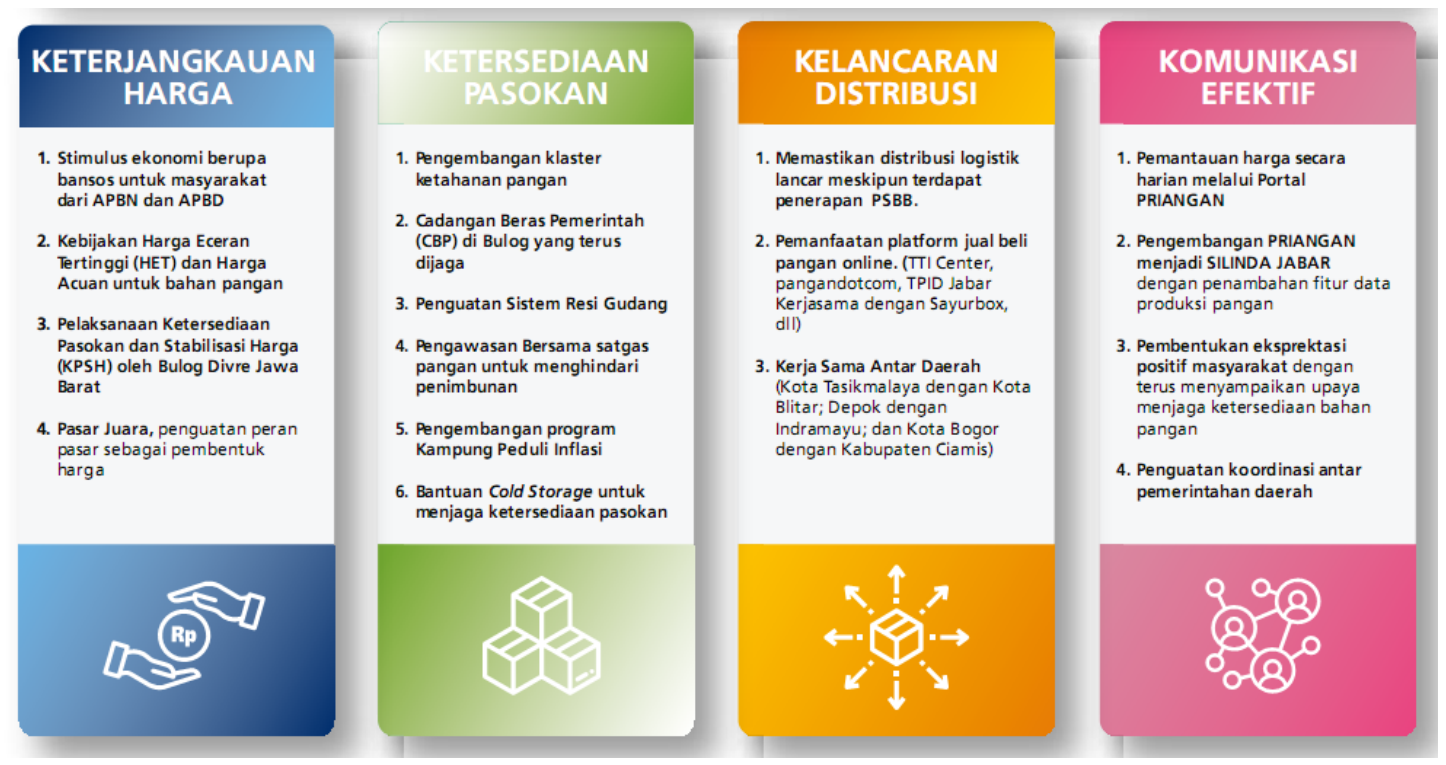

Gambar 2. Program Strategis Pengendalian Inplasi TPID Jawa Barat

Perbankan memberikan support modal pada petani untuk melaksankan dan pengembangan usaha, Stakeholder dan pelaku pasar memberikan pendampingan dalam keterajaminan harga dan pasar untuk memenuhi rantai pasokan. Manajemen rantai pasok (SCM) memegang peran penting dalam rantai pasokan sebagai salah satu bukti pemanfaatan teknologi, khususnya teknologi komunikasi dan informasi, untuk menggali kemungkinan-kemungkinan yang lebih luas dalam manajemen kapasitas produksi (Marina, 2019). Pada saat pendampingan, para petani memberikan respon positif berupa diskusi terkait operasionalisasi produksi dan pengolahan hasil produksi cabai. Sementara ini cabai yang dihasilkan digolongkan berdasarkan ukuran ke dalam 3 bagian yaitu ; Super, Sedang Besar (SDB) dan Kecil (Cakra). Cabai yang super dan SDB di pasarkan ke Bandung, Jakarta, Cirebon dan sekitarnya. Sedangkan untuk katagori cakra perlu penanganan lebih lanjut berupa olahan produk hasil pertanian berupa chili oil, cabai bubuk, cabai kering, dan cabai acar. Namun pengolahan cabai tersebut masih harus terus dikembangkan lagi sebagai bahan untuk kegiatan PKM selanjutnya. 

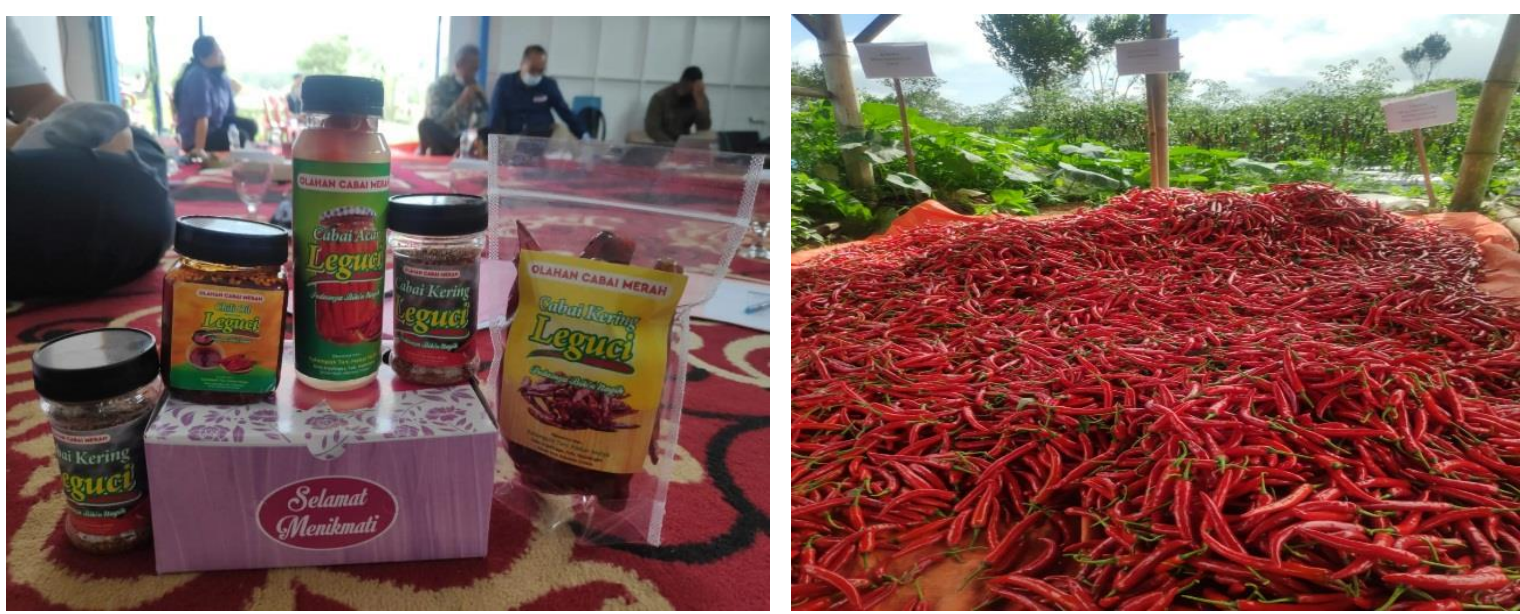

Gambar 3. Pengolahan Hasi pertanian Produk Cabai Merah

Produksi olahan cabai merah saat ini belum dilakukan secara rutin masih terkendala oleh tenaga produksi yang terbatas. Sedangkan untuk pemasaran akan dilakukan melalui ASPARTAN dan Pasarmu.id. berdasarkan hasil pendapingan tim PKM menawarkan berbagai pengolahan yang dapat dilakukan beserta kemasan yang lebih menarik untuk produk-produk hasil olahan cabai. Tim PKM memberikan penjelasan terkait promosi produk yang dapat dilakukan mulai dari promosi door to door sampai promosi yang melibatkan pengembangan komunikasi digital.

\section{Kesimpulan}

Kegiatan pendampingan akan terus dilakasanakan setiap bulan pada kelompok tani Mekarmulya sebagai mitra kerja antar IDUKA dan Perguruan Tinggi. Materi yang disampaikan pada kelompok tani berupa peramalan produksi dan permintaan merupakan hasil dari penelitian dengan data yang diperoleh dari lokasi yang dijadikan penelitian sebelumnya yang kemudian di lakukan analisis dan diinterpetasikan. Materi yang disampaikan mendukung kegiatan program pengendalian inflasi daerah TPID Jawa Barat. Program selanjutnya perlu dilakukan pendampingan juga penalitian lebih lanjut terkait dalam pengolahan atau disversifikasi produk olahan cabai merah dengan kualitas yang baik baik secara penampilan kemasan maupun mutunya serta penguatan kelembagaan wanita tani.

\section{Daftar Pustaka}

Bank Indonesia, (2021). Laporan Ekonomi Propinsi Jawa Barat 2021. htps://www.bi.go.id/id/publikasi/laporan/lpp/Pages/Laporan-Perekonomian-Provinsi-JawaBarat-Mei-2021.aspx.

Marina, Ida. (2017). Strategi Pengembangan Agribisnis Hasil Pertanian Melalui Inovasi dan Kreatifitas Menjadi Produk Unggulan di SMK Negeri 1 Pacet Kabupaten Cianjur. Mimbar Agribisnis: Jurnal Pemikiran Masyarakat Ilmiah Berwawasan Agribisnis 45-54.

Marina I,. Lestari DA. (2017). Pentingnya Data Deret Waktu Dalam Melakukan Perencanaan Produksi (the Importance of time Series Data in Production Planning). https://media.neliti.com/media/publications/175016-ID-none.pdf

Marina, Ida. (2019). Model Kapasitas Produksi Tomat Di Sentra Produksi Kabupaten Majalengka. Agrivet: Jurnal Ilmu-Ilmu Pertanian dan Peternakan (Journal of Agricultural Sciences and Veteriner) 
BERNAS:

Jurnal Pengabdian Kepada Masyarakat

[Vol. 2. No 3, 2021. pp. 775-779]

779

Pusat Data dan Informasi Pertanian. (2016). Outlook komoditas sub sektor hortikultura: cabai. Jakarta (ID): Pusat Data dan Informasi Pertanian.

Saptana, Rachman HPS. (2015). Tinjauan konseptual makro-mikro pemasaran dan implikasinya bagi pembangunan pertanian. Forum Peneliti Agro Ekon. 38(2):1-18. 